Tez Özeti

\title{
Yeni Dönem Alman Gerçekçi Televizyon Dramalarında Postmodern Ögeler*
}

\author{
Hasan Gürkan (Dr. Öğr. Üyesi) \\ İstanbul Arel Üniversitesi İletişim Fakültesi \\ gur.hasan@gmail.com \\ ORCID: 0000-0002-3805-9951 \\ Betül Doğan \\ İstanbul Arel Üniversitesi Sosyal Bilimler Enstitüsü \\ betuldogannn@gmail.com \\ ORCID: 0000-0002-0865-9892
}

Başvuru Tarihi: 25.09.2019

Yayına Kabul Tarihi: 02.12.2019

Yayınlanma Tarihi: 24.01.2020

DOI: http://10.17680/erciyesiletisim.624347

\section{Öz}

Bu çalışma, "Yeni Dönem Alman Gerçekçiliğgi" ana başlığı çerçevesinde ele alınmaktadır. Bu kapsamda, çalışmada, Dark (2017), Dogs of Berlin (2018) ve Perfume (2018) dizileri niteliksel içerik analizi yöntemi ile incelenmekte ve bu dizilerin postmodernist ögelerle olan ilişkisi tartışılmaktadır. Bu dizilerde günümüze kadar iktidar, güç temsili, sağduyulu ve iyi görülen kanun insanı profili incelemelerine yer verilmektedir. $\mathrm{Bu}$ dizilerin incelenmesindeki en önemli faktör üçünün aynı platform üzerinden yayınlanmaları, birbirlerine yakın tarihli yapımlar olmaları, aynı türde olmaları (polisiye-suç) ve her birinde kanun insanı karakterinin yer almasıdır. Çalışmanın amacı; yeni dönem Alman dramalarında kanun insanlarının bu dizilerin olay örgüsünde önemli roller aldığı ve yakın zamana kadar kabul gören kanun insanı profilinin bu yapımlarda nasıl değişime uğradığının incelenmesidir. İncelenen dizilerde kanun insanları, kişi-karakter yansıması çerçevesinde incelenmekte ve geçmiş dönemdeki kanun insanı profilleri ile benzerlikleri/ farklılıkları tartışılmaktadır. Bu incelemeler sonucu söz konusu dizilerde postmodern kişi-karakter yansıması olarak bakıldığında "kanun insanı profili”nin ana akımda yer alan; kabul görmüş şeklinden farklı kodlandığı görülmektedir. Kanun insanları "güç temsili, sağduyulu, iyi insan" kavramlarından çok "aldığı kararlarda duygularının önemli rol taşıdığı, suç işleyen ve çıkarcı” gibi durumları da kapsayacak şekilde yeniden şekillendiği görülmektedir.

Anahtar Kelimeler: Dark, Dogs of Berlin, Perfume, Netflix, Postmodernizm.

\footnotetext{
* Bu çalışma İstanbul Arel Üniversitesi Sosyal Bilimler Enstitüsü'ne 2019 yılında Betül Doğan tarafından sunulan "Yeni Dönem Alman Gerçekçi Televizyon Dramalarında Kanun İnsanlarının Profili” başııkı yüksek lisans tezinden türetilmiş makaledir.
} 


\title{
Postmodern Elements in the New German Realistic Television Dramas
}

\author{
Hasan Gürkan (Asst. Prof. Dr.) \\ İstanbul Arel University Faculty of Communication \\ gur.hasan@gmail.com \\ ORCID: 0000-0002-3805-9951 \\ Betül Doğan \\ İstanbul Arel University Institute of Social Sciences \\ betuldogannn@gmail.com \\ ORCID: 0000-0002-0865-9892
}

Date Received: 25.09.2019

Date Accepted: 02.12.2019

Date Published: 24.01.2020

DOI: http://10.17680/erciyesiletisim.624347

\begin{abstract}
This study is dealt with the title "the new German Realism". In this context, Dark (2017), Dogs of Berlin (2018) and Perfume (2018) series are examined with content analysis method and the relationship between these series and postmodernist elements is discussed. In these series, the state power, representation of power, common sense and well-known law profile are examined. The most important factor in examining these series is that three of them are broadcast on the same platform, they are recent productions, they are of the same genre (crime) and each one has the law person character. The purpose of the study is that how the law people play an important role in the plot of these German dramas and how the profile of these law people is changed in these productions. In the series examined, the law people are examined within the framework of personcharacter reflection and the similarities/differences with the profiles of the people of the past are discussed. As a result of these investigations, when the postmodern personcharacter reflection is considered in the series, it can be stated that the law person is coded differently from the accepted (mainstream) form. It is seen that the emotions play an important role in the decisions taken by the people rather than the concepts of power representation, common sense, good person, and they are reshaped in such a way as to include crimes and perpetrators.
\end{abstract}

Keywords: Dark, Dogs of Berlin, Perfume, Netflix, Postmodernism. 


\section{Giriş}

Medya izlerkitleyi etkileyerek, nostaljik duyguları tetiklemektedir. Özellikle son 20 yıldır medyada gördügüüüz görsel kültür ürünlerinin (TV dizileri, filmler, müzik videoları, vb.) nostaljik dünyanın estetiğinde tasvir edilmektedir. $\mathrm{Bu}$ nostaljik görsel medya metinleri, izleyicilerin "geçmiş" için acı çekmelerini veya özlem duymalarını sağlarken, aynı zamanda da onların (izleyicilerin) tedavisi için önemli bir yerde durmaktadır. $\mathrm{Bu}$, aslında medyanın kendisinin yaratmış olabileceği bir kavram olmakla birlikte, medyanın kendisi bir noktadan sonra nostaljinin teknolojik nesnesi haline gelmektedir. Bu noktada medya, sürekli geçmişe atıfta bulunarak ve geçmişi hatırlatarak nostaljik bir öğe haline gelmektedir.

Bu çalışmada son dönemde çekilen ve Netflix'te yayınlanan Alman yapımı üç dizi ele alınmaktadır. Çalışmanın amacı; yeni dönem Alman dramalarında kanun insanlarının bu dizilerin olay örgüsünde önemli roller aldığı ve yakın zamana kadar kabul gören kanun insanı profilinin bu yapımlarda nasıl değișime uğradığının incelenmesidir. İncelenen Dark (2017), Dogs of Berlin (2018) ve Perfume (2018) dizilerinde kanun insanları, kişi-karakter yansıması çerçevesinde incelenmekte ve geçmiş dönemdeki kanun insanı profilleri ile benzerlikleri/farklılıkları tartışılmaktadır.

Çalışmanın varsayımı şu şekildedir: Birer Netflix yapımı olan ve gösterimi Netflix üzerinden gerçekleșen Dark (2017), Dogs of Berlin (2018) ve Perfume (2018) dizilerinin olay örgüsünde yer alan kanun insanı karakterleri ana akımdaki karakterlerden farklı temsil edilmektedir ve bu yapımlarda çokça postmodern öğelere rastlanmaktadır. $\mathrm{Bu}$ dizilerin incelenmesindeki en önemli faktör üçünün aynı platform üzerinden yayınlanmaları, birbirlerine yakın tarihli yapımlar olmaları, aynı türde olmaları (polisiyesuç) ve her birinde kanun insanı karakterinin yer almasıdır.

\section{Televizyon Dizileri ve Türleri}

Televizyon yayıncılığı dendiğinde akla ilk gelen program türü kuşkusuz dizilerdir. Televizyon dizileri literatürde farklı kelimler ile anılmaktadır: seriyal, arkası yarın, sabun köpügü (soap opera), pembe dizi, vb. Mutlu (1999, s. 197) genel olarak bakıldı̆̆ında televizyon dizilerinin, aynı sinema filmlerinde olduğu gibi anlatıya (olay örgüsü, hikâye) sahip yapımlar olduğunu söylemenin mümkün olduğunu belirtmektedir. Tanrı̈ver (2010, s. 112) dizilerin bir televizyon program türü olarak birçok alttüre ayrıldığının altını çizmektedir. Ancak tanımların anlamını yitirdiği ve zorlaştığı günümüzde, televizyon dizilerinin yalnızca bir tür (macera, gerilim, korku, melodram, vb.) içerisinde değerlendirilmesi oldukça zordur. Örneğin Holdges (2008) çalışmasında, televizyon dizilerinin türleri konusunda, tek bir türden bahsedilemeyeceğini, dizilerin birden fazla türü barındırdıklarını ve melez türlerden bahsetmenin mümkün olduğunu dile getirmektedir.

Televizyon dizileri, diğer televizyon programlarından (haberler, reality şovlar ${ }^{1}$, gündüz kuşak programları, vb.) farklılıklar göstermektedir. Örneğin haber programları, gerçeklik televizyonları ya da gündüz kuşak kadın programları her gün yayınlanırken, diziler ise çoğunlukla haftada bir gün şeklinde yayınlanmaktadır. Bununla birlikte, televizyon dizileri ile izleyici arasında özdeşleşme sağlandığını belirtmek mümkümdür. Bu durumu, özellikle bir zamandan sonra izler kitle üzerinde dizi karakterlerinin etkilerinin görülmeye başlanması şeklinde ifade etmek de olasıdır (Erdem ve Çağlayandereli, 2006, s. 17). Toplum odaklı hazırlanan çalışmalar 'kamu yayıncılığı' (örneğin Türkiye'de kamu yayıncılığı TRT ile başlamıștır ve devam etmektedir) adı ile anılmaktadır. 


\section{Görsel Kültür ve Postmodernizm}

$\mathrm{Bu}$ bölümde sinema ve dizilerde postmodern etkiler hakkında bilgi vermek elzem görünmektedir. Postmodernizm etkileri görsel kültür ürünlerinde sıklıkla kullanılmaktadır. Filmler ve TV dizileri, kültürel araştırmaların, önemli bir bir bilgi kaynağıdır. Özellikle birçok sinema filmi ve TV dizisi üzerinden kitlelere (izleyicilere) din, kültür, gelenek, ahlak, inanç, ideoloji empoze edilmektedir. Arnold (2008), günümüzdeki TV dizilerinin çoğunun, postmodern bir sistemin parçası olan metinlerarasılığın bir uzantısı olduğunu ve TV dizisinin kültürel bir uygulama olarak üretilmesinin, metinlerarasılığın kullanılarak uygulandığı geniş kültür içinde hiçbir zaman bağıșıklık kazanmadığını belirtir. Lembo (2003) ise, eleștirmenlerin postmodern bir çağda yaşadığımızı söylediklerinde, izleyicilerin kendilerini etkilemeye devam eden metne olan canlı ilgisini diriltmek için film ve TV dizisi gibi çeşitli popüler biçimlerde edebi/ popüler metinleri yansıtması gerektiğini iddia eder. Popüler TV dizileri de bunu yapma eğilimindedir. TV dizilerindeki postmodern stil, yerelliği sınırlandırmakta ve postmodern estetik ile ilişkilendirilen "sürekli olumsuzlama" sanatını nasıl ve ne ölçüde yansıtabileceği sorununa odaklanmayı mümkün kılmaktadır.

Sanatta postmodern arayışlar yazın alanında ortaya çıkan metinlerarasılık kavramına ulaşmış ve bu kavram görsel kültür ürünlerine de uyarlanmıștır. Pastiş ve parodi yani öykünme ve yansılama işlemleri, metinlerarasılık olarak ifade edilen kavramlardır. Kısaca daha önceden yapılana bir gönderme yapılarak tekrar ve taklit edilmesidir (Sim, 2006; Gürkan, 2012; Günay, 2003). Fakat parodi ve pastişi ayıran; parodinin alaycı tavrı sonucu güldürmesi, pastişin ise öncekine saygısını sunmasıdır. İkisinin de özünde taklit yatsa da pastişte önceden yapılanı benimseyip aktarma vardır (Karaburgu, 2008).

Görsel kültür ürünlerinde pastiş sadece daha önceden yapılanı göstermek değildir. Çalınan şarkılar, gösterilen tablolar, okunan dualar ve şiirler gibi unsurlarla da yapılabilmektedir. Pastiş bir döngüdür. Pastiş geçmişte yapılanın bir taklidi olduğu için ister istemez yanında nostaljiyi de getirmektedir. Nostalji ögesi de postmodern ürünleri oluşturan unsurlar arasında yer almaktadır. Filmlerin ve TV dizilerinin geçmişte kalan mekânlarda geçmesi, günümüzde kullanılmayan, eskide kalmış eşyaların dekor olarak kullanılması, saç ve makyajların geçmiş bir tarihin modasına göre yapılması izleyiciye o tarihi yeniden yaşatmaktadır. Bu anlatılarda geçmiş, pastiş olarak kullanılmakta ve izleyiciye nostalji yaşatılmaktadır. "Geçmiş", görsel kültür ürünlerinde yeniden üretilir ve sürekli tüketilmekte olan bir metaya dönüştürülür. Bu durum, nostaljiyi daha değerli hale getirir. Postmodernizmin kronolojik devam etmeyen zaman çizelgesinde; geçmiş, şimdi ve hatta gelecek birlikte (bir arada) olur. Postmodern görsel kültür ürünlerinde zaman ve mekânın kırılması da önemli rol oynamaktadır (Akay, 1992, s. 26; Gürkan, 2012, s. 104). Jameson'ın (1991) belirttiği gibi, geçmişe (nostaljiye) yüklenilen bu olumlu anlam, eskinin șimdiye nazaran daha yaşanabilir olduğunu gösterir ve Jameson (1991) bunu, geçmişe duyulan özlem olarak adlandırmaktadır. Ancak genel olarak televizyon ve özellikle televizyon dizileri nostalji ile daha karmaşık bir ilişki içerisindedir. Nostaljik bir dizi, genellikle izleyicisinin özleminin nesnesidir. Aynı zamanda, nostalji, televizyon dizilerinin ilgisini çekmek için tercih edilen konulardan biri gibi görünebilir.

Burada dikkat edilmesi gereken; her dönem filmini ya da TV dizisini (dönem anlatılarını) nostalji unsuruyla karıștırmamak gerektiğidir. Bu ürünlerin oluşturuluş şeklinde nostalji ne kadar yer tutmaktadır? Anlatımın bir parçasında geriye dönüş ve nostalji ögesinden mi yararlanılmıştır yoksa anlatımın kendisi bunun üzerine mi kuruludur? İspir ve Kaya $(2011,86)$ görsel kültür ürünlerinde kullanılan pastişi şöyle yorumlamıştır: "Burada 
pastişin görsel ürünün ana unsurunu oluşturmadığı, sadece anlatıma katkı sağlamak ve oyunun hikâyeye bağımlı olmaksızın ilerleyişini sağlamak amacıyla yapılan teknik alıntılamadan ibaret olduğu görülmektedir." Bu durumda kullanılan pastiş ögesi, bir görsel ürünü postmodern yapmaya yetecek bir unsur değildir. Pastiş unsurunun kullanım amacına ve fonksiyonuna bakılmalıdır.

Televizyon dizilerinde ve filmlerde postmodernizimden bahsederken kurgu, büyük önem arz etmektedir. Modernist sinemanın kurgusunda öykülemeci anlatım vardır. Hikâye başlatılır ve bitirilir. Bu durum edebiyatta da mevcuttur. Modern romancılar da anlatımlarını aynı şekilde sıralamaktadır. Her ikisinin de kullandığı kurguda; bir olay açıklanarak bir sonuca bağlanmaktadır. Postmodern sinemada kullanılan dil aynı olsa da modernden ayıran; amaç ve işlevdir. Postmodernist görsel kültür ürünlerinde, anlatının ana akım gelenekleri altüst ettiğini söylemek mümkündür. Nostalji, muhafazakâr bakış, geçmişe duyulan özlem, geçmiş-şimdi-gelecek arasında sınırların ortadan kalkması postmodern yapımların en belirgin özellikleri arasında yer alır (Gürkan, 2012; Jameson, 1991).

\footnotetext{
"Modern sinemanın aksine postmodern yaklaşımda kurgunun kullanım amacı gerçekçi ve öykülemeci bir anlatım ortaya koymak, ikili karşıtlıkları sunmak yahut sanatsal kaygılar taşıyan bir eseri ortaya koymak değildir. Kurgu ve öykü, postmodern yüzeyselliği barındıran ve gösterilenden çok gösterene önem veren bir yapıtı ortaya koymak amacıyla kullanılan araçlardır. Böylelikle yüzeysellik içeren ve biçimi anlama tercih eden yaptın dili parçalı bir dil olmakta ve öykü bütünsellikten uzaklaşmaktadır." (İspir ve Kaya, 2011, s. 91).
}

Televizyon dizilerinde postmodern öğelerinin en çok karşılaşıldığı dizi olarak Tudor (2012) Mad Men dizisini örnek verir ve bu dizinin medyadan türetilmiş nostaljide yer alan ve kültürel olarak postmodern temsil kavramlarını vurgulayan bir dizi olduğunu vurgular. Bu düşünce, postmodern kültürü, temsilin gerçeğin yerine getirdiği biçimiyle teorize eden, ancak günlük yaşamın koşullarına yansımasını teşvik etmeyecek şekilde kurarken, diğer taraftan Foster (1989) bunun, Jean Baudrillard'ın çalıșmalarına dayandığını iddia eder. Postmodern ve neoliberal nostalji, izleyicilerin 1960'ların Mad Men modası, cinsiyetçiliği ve ırkçılığı için 1960'lı yılların nostaljisinden, dizinin cinsiyetçiliğini/ ırkçılığını kabul etmesini sağlayan neoliberal post-cinsiyetçilik/ırkçılık fikrinin ithalatına geçmesine olanak tanıyan temsillerle çalışır. Buna ek olarak, dizinin bazı izleyicileri 1960'ları yalnızca televizyon görüntüleri ile tanır. John Kennedy'nin şovdaki karakterlerin televizyonda izlediği suikastı, ara sıra ortaya çıkan orta söylemin belirleyicileri olarak popüler söylemde yeniden dolaşımda olanlarla aynı dönemlerde yaşanır. Holdges (2008) ise, yaptığı çalışmasında The X-Files dizisindeki postmodernist öğeleri 'türler arası geçiş, melezlik' olarak özetlemektedir. Popüler TV dizilerinin postmodern özellikler gösterdiğini iddia eden Hodges (2008), bu özelliklerin türler arası bir noktada durduğunu ve yeni melez türlerden bahsetmenin münkün olduğunu belirtir.

\section{Yöntem}

Çalışmada nitel araştırma yöntemlerinden biri olan içerik analizi tekniği kullanılmaktadır. Nitel analiz, sosyal olay ve olguların; insanların yaşam tarzlarının, örgütsel yapılarının anlaşılması ve toplumsal değişmeyi anlamaya dönük sosyal bilimlerin kullandığı araştırma ve bilgi üretme süreçlerinden biridir (Özdemir, 2007, s. 339).

$\mathrm{Bu}$ teknik görsel kültür ürünlerinin analizinde de kullanılan bir tekniktir. Özdemir (2007, s. 335) araştırmacının, araştırma konusuyla ilgili kategoriler geliştirmesi, daha sonra bu kategoriler içerisinde yer alan kelime, cümle veya resimleri saymasını söyler. 
Bu nedenle, bu çalışma Susanna Priest'in içerik analizi yöntemini takip eder ve Priest'in (1996: 23) belirttiği gibi "insanlar hakkında bir şeyler öğrenmeye çalışmanın, onların yazdıkları, televizyonda ürettikleri TV dizileri ve filmleri..." inceleyerek ulaşılabileceği fikrinden hareketle, çalışma bir sonuca varmaya çalışmaktadır. Bu çalışmada nitel analiz, tümdengelimci bir yol takip edilerek, araștırmaya dâhil edilen son dönem üç Alman dizisinin incelenmesi ile yapılmaktadır.

Bu bağlamda, bu üç dizinin seçilmesinde kanun insanlarının hikâyeye doğrudan etki etmesi etkili olmuştur. Bu doğrultuda çalışmanın örneklemini oluşturan Dark, Dogs of Berlin ve Perfume adlı diziler amaca uygun olarak belirlenmiştir ve incelenen dizi bölümleri postmodern bulgulara en sık rastlanılan üç bölüm olarak amaçsal örneklem doğrultusunda seçilmiştir. Dark dizisinin "Sırlar, Geçmiş ve Günümüz, Ne Ekersen Onu Biçersin"; Dogs of Berlin dizisinin "Takım, Kolay Maç, Zafer Kutlaması"; Parfume dizisinin "Skatol, Sentez, Kalp Notaları" bölümleri incelemeye alınmıştır.

\section{Bulgular}

\section{Dark Dizisinde Postmodernist Bulgular: Bölüm 1 "Sırlar"}

$\mathrm{Bu}$ dizideki postmodern ögeler daha çok metinlerarasılık ve nostalji (geçmişe duyulan özlem) olarak yer almakla beraber izleyicide zaman - mekan algısını kıran sahnelere yer verilmektedir. Dizi, metinlerarasılık örneğiyle başlamaktadır. Metinlerarasılık Albert Einstein'in² şu sözleriyle yapılmıștır: “Geçmiş, şu an ve gelecek arasındaki fark inatçı bir illüzyondan ibarettir...”: "Şekil 1.”. Bu sözü destekleyecek bir anlatımla sürdürülür.

21 Haziran 2019. Sonradan Jonas'ın babası olduğu öğrenilen Michael 21 Haziran 2019'da bir mektup bırakarak intihar eder. Mektubun üzerinde "4 Kasım 22:13'ten önce açmayın" yazmaktadır. Einstein'in sözü, dış sesin anlatımı ve mektubun üzerindeki bu yazı; izleyiciye zaman kavramı üzerine bir șeyler izleteceğine dair vaatlerde bulunmaktadır. Michael'in kendini astığı sahnede eşlik eden ses efekti ile Jonas'ın terler içinde uyanmasıyla devam eder.

Ulrich evine gelmiştir. Mikkel, Houdini ${ }^{3}$ gibi olmak istediği için sihirbazlık numaraları yapan bir çocuktur. Üstündeki kostümü "iş kıyafeti" olarak görmektedir. Babasına küçük bir sihirbazlık gösterisi yapar. İki bardaktan birinin altına koyduğu nesne diğer bardağın altından çıkar. Burada kesme kullanılmamış sahne akıtılmıştır. Böylece seyircinin de gösteriden etkilenmesi beklenmiş ve Houdini yüceltilerek karakterler arası bir bağ kurulmuştur. $\mathrm{Bu}$ da metinlerarasılık örneğidir. Babayla arasındaki diyalog dizinin tümünde akılda kalması gereken cinstendir:

Ulrich: İnanılmaz. Nasıl yaptın bunu?

Mikkel: Baba, asıl soru nasıl değil ne zaman yaptığım. (Dark, Sezon 1, Bölüm 1: 12:43) Mikkel'in kostümüyle ilgili birkaç nokta vardır: bunlardan ilki bölüm sonunda başına geleceklere bir göndermedir. İkinci olarak "Houdini gibi kaçıp kurtulabilecek mi?" sorusunu akıllara getiren bir faktördür. Ayrıca bu kostümün tercih edilmesiyle metinlerarasılık örneği ortaya çıkmıştır. Yönetmenliğini Richard Kelly'in yaptığı Donnie Darko (2001) filmine bir gönderme bulunmaktadır: "Şekil 2."

Ulrich'in annesinin ormanda bir şeyler gördügünü söyler. Erik'in kaybolmasının Mads'in kaybolmasına benzediğini söylerken; ormanda bulduğu çikolata paketini gösterir: "Şekil 3." Mads'in en sevdiği çikolatadır. Çikolata nostalji unsuru olarak kullanılmıştır. Günümüzde Almanya'da Raider adıyla üretimi yoktur. Bu çikolata ilk kez 1967'de İngiltere'de Raider 
adıyla üretilmiş ve 1979 'da Twix adıyla satışa sunulmuştur. (marketingturkiye, 1998) Anne her șeyin tekrar ettiğini, her șeyin 33 yll önceki gibi olduğunu ileri sürmektedir.

Bölümün tek aydınlık mekânında Erik görünür. Duvar kâğıtlarıyla renklendirilmiş odada birkaç parça oyuncak, çalışma masası, televizyon, ranza ve ortada garip bir mekanizma bulunmaktadır: "Şekil 4" Odada bulunan her eşya eskiyi hatırlatmaktadır. Erik televizyonda çalan müziğin sesinden rahatsızdır. Televizyonda Dead or Alive grubunun "You Spin Me Round" klibi yayınlanmaktadır. Şarkının sözleri Erik'in içinde bulunduğu durumla çelişkili şekilde eğlencelidir. Şarkının "Beni döndürüyorsun... Evet, senin ismini biliyorum... Çok eğlenmiş gibi görünüyorsun... Bakışlarım üstünde" gibi sözleri Erik'in izlendiği, bilindiği ve rahatsız bir durumda olmasıyla bağdaştırılmıştır. Elektro Pop türünde olan bu şarkının çıkış yılı 1985'tir. Nostalji ögesi olarak yer alan bu klip Sanyo marka tüplü televizyonda gösterilmektedir. Sanyo 1947 kuruluşlu bir markadır. 2010 yılında Panasonic tarafından satın alınmıştır ve günümüzde bu televizyon bulunmamaktadır. Bu mekâna girildiğinde olayın geçmişte mi geçtiği yoksa birinin geçmişi mi yaşatmaya çalıştığı tam olarak anlaşılmamaktadır.

Ormanda arkadaşlar yürümeye devam ederlerken Mikkel'in Erik'e ne olduğunu merak etmesi üzerine konuşma başlar. Martha Mikkel'in korkmaması için elinden geldiğinde konuyu yumuşatmaya çalışmaktadır. Erkekler onun kadar iyi yaklaşmazlar. Martha'nın sevgilisi Bartosz, Hansel ve Gretel'deki ${ }^{4}$ cadıdan bahsetmiş, Martha onu susturmuştur. Erik'i kaçıran kişiyle Hansel ve Gretel'deki cadıdın benzetilmesi dizideki metinlerarasılık örneklerinden biridir. Ayrıca bu konuşmada kadın ve erkeğin olaya bakış açılarını göstermelerinin yanı sıra küçük bir çocuğa da nasıl yaklaştıklarının farkları da gösterilmiştir. Mikkel'in "Ölsen bile bulunmak istersin.” cümlesi bölüm sonuna bir gönderme yaparak yeniden hatırlanacak ve bu masum cümle izleyiciyi üzecektir.

Mikkel mağaranın derinliğine doğru gözlerini dikmiş bakarken nefes nefesedir. Magnus'un "Koşun” demesiyle kaçışırlar. Ancak ne Martha ne Magnus, kardeşleri Mikkel'i hatırlamaz. $\mathrm{Bu}$ arada annenin mektubun diğer sayfasına geçtiği görünür; ağlayarak okumaktadır. Jonas ve Mikkel geride kalmıştır. Jonas'ın yere düşmesiyle yükselen ses susmuş ve yerini ortam sesine bırakmıştır. Mikkel'e seslenir ancak Mikkel gözden kaybolmuștur. Babasının kendisine seslendiğini duyar; arkasını döndügünde babasının kanlar içindeki hayaletini görür ve korkarak kaçar: "Şekil 5." Babanın görünen hayaletiyle yeni bir metinlerarasılık örneği oluşturulmuştur. Hayalet imgesi Shakespeare'in Hamlet'ine bağlanmıştır. Babasının hayaleti, sorunu çözmesi için kahramana yani Jonas'a baskı uygulamaktadır. Jonas, dizinin sonunda öğreneceğimiz üzere babasının çocukluğu ve hayaleti arasında yalnız bırakılmıştır.

Ulrich'in polislik ve babalık kimlikleri birbirine karışmıştır. Peter panik halde Charlotte'u arar. Önemli bir şey söyleyecek gibidir ancak Charlotte iş sebebiyle kapatması gerektiğini söylemiştir. Peter dua etmektedir:

"Tanrım, değiştiremeyeceklerimi kabullenmek için sabır, değiștirebileceklerimi değiştirmek için cesaret, farkı anlamak için akıl ver." (Dark, Sezon 1, Bölüm 1: 44:59-45:12)

$\mathrm{Bu}$ dua dizideki yeni bir metinlerarasılık örneğidir. Dua Hitit duasıdır. Hititlerin duvar yazısından alındığı söylenmektedir. Milattan önce 2000'li yıllara aittir ${ }^{5}$. 
Polislerin aramaları sonucu bir çocuk bulunur. Ulrich'in olay yerine gelmesiyle çocuğun Mikkel olmadığı tespit edilir. Ölü çocuğun yanında Sony WM-22 model kasetçalar bulunmaktadır. İçindeki kaset çalmaya devam etmektedir. Kamera kasetçalara yaklaştığında melodi duyulmakta ve bir sonraki sahne olan Erik'in tutulduğu odadaki televizyonda yayınlanan kliple birleşmektedir. Bu klip Nena'nın 1984 yılında yaptığı Irgendwie, Irgendwo, Irgendwann adlı şarkının klibidir. Nostalji unsurlarının birleștiği bu iki sahneyi birbirine bağlayan müziğin ilki Sony'nin 80'li yılların bașında ürettiği bir kasetçalardan sonrasında ise yine günümüzde kullanılmayan Sanyo televizyondan dinletilmiştir. Şarkının sözleri dizinin temasına uygun şekilde zaman ve mekândan bahsetmektedir.

\section{Bölüm 3 "Geçmiş ve Günümüz"}

Önceki bölüm sonunda Mikkel evinin önüne geldiğinde anne ve babasının lisedeki halleriyle karşılaşmıştır. Kapıda duran gazeteden 1968 yılına geldiğini anlamıştır. Mads'in kaybolmasından 4 hafta sonraya. Mikkel evin açık kapısından içeri girdiğinde bir kadının televizyon karşısında uyuduğunu görür. Önceki bölümlerde de karşımıza çıkan ve nostalji unsuru olarak kullanılan çikolata bu bölümde de televizyon reklamı olarak görünmektedir.

5 Kasım 1986. Radyodaki haberlerde; 4 hafta önce kaybolan 11 yaşındaki Mads'in bulunamamasıyla ilgili yerel polise halkın tepkisinin olduğu söylenmektedir. Komiser Egon Tiedemann haberi 1984 yılında üretilmiş Alman markası olan Grundig RF 425 marka radyodan dinlenmektedir: "Şekil 6." Egon'un ofisinde Mads'in fotoğrafının da olduğu haberler panoya yapıştırılmıştır. Egon'un masasında hiç o ortama ait değilmiş gibi duran zekâ küpü bulunmaktadır. Durumu çözememiş bir komiser ve masasında belli ki çözmeye çalıştığı ama başaramadığı bir rubik küpü ironiktir: "Şekil 7." Zekâ küpü adıyla da bilinen bu bulmaca oyuncağı Ernő Rubik tarafından 1974 yılında icat edilmiş ve 80'li yılların simgesel oyuncaklarından biri haline gelmiştir. Böylece seyirci bir dizi nostalji unsuruyla buluşturulmuştur.

Sonraki sahnede Egon'un kızı Claudia araç hazırladığı konuşmayı prova etmektedir. Claudia yeni işine gitmektedir. Kurul yöneticiliği pozisyonu ilk kez bir kadına vermiştir. Bu durum 80’ler için yeni sayılmaktadır. Arabanın radyosunda Tears for Fears grubunun "Shout" adlı şarkısı çalmaktadır. 1984 yılında çıkardıkları bu şarkı popüler olmuş ve 1985'te İngiltere'nin en iyi 5 gözde parçasından biri ilan edilmiştir' ${ }^{6}$. 1986'da geçen bu sahne de şarkının popülerliğini koruduğu dönemdendir ve nostalji unsuru olarak kullanılmıştır. Mikkel şaşkınlıkla öğrencilere bakmaktadır. Yüksek bel pantolonlar, kızların kabarık saçları, karpuz kollu ceketler seyirciye 80’leri yeniden yaşatmaktadır. Adamın birinin bir kızı sırf kırmıjı ruj sürdüğü için ormana kaçırıp öldürdüğünü söyler. Hannah babasının sadece fahișelerin kırmızı ruj sürdüğünü söylediğini anlatır. 0 dönem yeni yeni moda olan kırmızı ruj nostalji unsuru olarak yer almakta ve halkın bu yeniliğe önyargısı dile getirilmektedir. Mikkel onlara okulun müdürünün annesi olduğunu ve onu aradığını söyler. Ancak annesi Katharina yani Mikkel'in konuştuğu kişi okul müdürünün erkek olduğunu söyler ve omuz atarak gider. Postmodern ögelerden biri olan zaman ve mekân karmaşı bu sahnede çok net bir şekilde karşımıza çıkmaktadır.

Claudia iş yerinin önündeki dönemin arabalarıyla renklendirilmiş otoparktan çıkıp santrale gireceği esnada Helge ona bir kitap hediye eder. Claudia'nın gitmesiyle birlikte Helge'nin 80'lerin meşhur "No Future" sloganını firçalayarak çıkarmaya çalıştığı görülmektedir:"Şekil 8." 
Sonraki sahnede Egon ölü koyunların arasındadır. Koyunların sahibi ısırık izi ya da başka bir şey görmediğini söyler ve çocuğun kaybolmasından sonra koyunların bu şekilde ölmesinin şaşkınlığı içindedir. 33 tane koyun ölmüştür. Koyunların sahibi Markos İncili'nden alıntı yapar: "Gözünüzü açın. Dikkat edin. Vakit ne zaman gelir, bilemezsiniz." Markos İncili, 13:33. Dizideki 33 yıllık arayla geçmiş ve geleceğin gösterilmesi ve 33 koyunun ölü bulunması 33 sayısına dikkat çekmektedir. 33 sayısı; Hz. İsa'nın 33 yaşında çarmıha gerilerek öldürülmesinde, gezegenlerin 33 yılda bir hizalanmasında, tespihin 33 kere çekilmesi ve 33 boncuklu olmasında karşımıza çıkmaktadır.

Egon Ulrich'in evine gelip Mads'in dönmesi ihtimaline karşı açık bırakılan kapıdan girer. Ulrich video oyunu oynamakta ve çok yüksek seste metal müzik dinlemektedir. Video oyunu dizi boyunca tekrar eden ögelerden biridir. Kreator grubunun Mayıs 1986'da çıkarttığı "Pleasure to Kill" adlı şarkı çalmaktadır. Ulrich'in yaşadığı Winden kasabasında nükleer santral olması ve Ulrich’in; Essen, Ruhr Bölgesi gibi noktalardaki sanayi kirliliğini konu edinen Kreator grubunun şarkılarını dinlemesi başka bir göndermedir. Buna karşılık, modernizmin endüstirileşmesine karşı postmodernizmin bunu kabul etmeyip üretim biçimlerini değiştirmemesi söylenebilir. Ulrich'in odasından çeşitli kareler sunularak Ulrich'in gençliği hakkında seyirci bilgilendirilir. "No Future" sloganı duvarında ve sandalyesinde duran kazağında yeniden karşımıza çıkmaktadır: "Şekil 9." Sloganın altında Winden tabelası spreylenmiş ve ortasına çarpı atılmıştır.

Koyunların ölümünü inceleyen adli tıpçı ani kalp durması olduğunu söyler. Koyunların kolay paniğe kapıldıklarını, hassas hayvanlar olduğunu söyleyen adli tıpçı ve Egon arasındaki diyalogta Freddy Krueger'den bahsedilmiştir. 1984 yapımı olan Elm Sokağı Kabusu filmi o yıllar için çok yenidir. Bu da yeni bir metinlerarasılık örneğidir.

Claudia görevi devralacağı kişiden nükleer santralle ilgili her şeyi öğrenmek istediğinde bu kişiyle birlikte mağaranın bulunduğu bölgeye yakın biryere gelirler. Adam anahtarı uzatırken "Bildiklerimiz bir damla. Bilmediklerimizse bir okyanus." der ve Claudia'ya anahtar ve fener verir. Newton'un bu sözünün kullanılması metinlerarasılık örneğidir. Sahnenin bir diğer metinlerarasılık örneğini adamın anahtarı tutuş şeklinde göstermek mümkündür. Baş ve işaret parmağının birleştirilmesi bir mudra7 örneğidir: "Şekil 10."

Hemşire Ines Mikkel'e okuması için "Captain Future"8 dergilerini bırakır. Bunun üzerine Mikkel ilk kez Ines'le konuşur ve ona gelecekten geldiğini söyler. Ines bunu derginin ismiyle bağdaștırmıștır. Zamanda Yolculuk adlı kitabın yazarı dizinin karakterlerinden olan saatçi H. G. Tannhaus'dur. Kitabın yayınevi “Mino Tauros" olarak görünmektedir: "Şekil 11.” Bu ismin tercihiyle Yunan mitolojisine gönderme yapılmış ve yeni bir metinlerarasılık örneği ortaya çıkmıştır. Minator mitolojide yarı insan yarı boğa olan bir canavardır.

Ulrich önceki bölümde kardeşinin kayboluşuyla alakalı bir bağlantı olabileceğine inanmış ve mağaraya arama izni çıkartmak istemiştir. Ancak reddedilmiştir. 2019 yılında izinsiz olarak mağaraya girer. 1986'da Mikkel mağaranın içindedir ve düşüp bacağını sakatlamıştır. 1986'da varilleri gördügümüz yere kapı yapılmıştır ve Ulrich o kapıyı açmaya çalışmaktadır. Ulrich polis olarak değil oğlunu kaybetmiş bir babanın öfkeli haliyle oradadır. Açılmayan kapıya sinirle vurmaktadır. Mikkel sesleri duyar ve seslenir. Ulrich oğlunun yardım çığlıklarını duymuştur. Sesin geldiği yöne gittiğinde mağaranın çıkışına varmıştır ve kimse yoktur. Ekranı yeniden ikiye bölerek sahne akıtılmıştır. Birbirinden 33 yıl farkla aynı anda mağaradadırlar. Birbirlerinin seslerini duymuş fakat birbirlerini görememişlerdir ve zaman-mekan kavramları üzerine yeni bir oyun oynanmıştır: "Şekil 12." 


\section{Bölüm 8 "Ne Ekersen Onu Biçersin”}

Bölüm W. Shakespreare'den bir alıntıyla; metinlerarasılık örneğiyle başlamaktadır. "Cehennem boş, şeytanlar burada!" Bu söz Shakespreare'in "Fırtına" isimli oyunundan alınmıştır. Genç Egon nükleer santrali inşaat alanında 2 çocuk cesedi görür. Çocuklara 1980'lerin kostümleri giydirilmiştir. Cesetler nükleer santral reklamı önünde durmaktadır. Reklamda “Önemli bir yatırım. Her ev için nükleer güç!” yazmaktadır. Günümüzde kıyafetlerde çıkartma olarak karşılaşılan bir görsel haline gelmiş bu reklam Almanya'da birçok insanın karşı çıktığı nükleer santral inşaatı ve önüne ölü çocukların konumlandırılması ironi yaratmıştır. Seyirciye Çernobil faciası hatırlatılmıștır. Önceki bölümlerde Jonas olduğunu öğrendiğimiz Yabancı, saatçi Tannhaus'un yanına gelmiştir. Tannhaus ona Einstein-Rosen Köprüsü teorisini anlatır. Bu teori Nathan Rosen ve Albert Einstein tarafından ileri sürülen Solucandeliği olarak da bilinen teoridir. Tannhaus'un anlattığı teori Ulrich'in mağaranın içindeki görüntüsü üzerine bindirilmiştir. Tannhaus'un teoriyi anlatırken Üçlü Dügüm'den bahsetmesi yeni bir metinlerarasılık örneği oluşturmaktadır: "Şekil 13." Triquetra bir Kelt sembolüdür. Hristiyanlık öncesi dönemde Kelt'lerin Pagan kültüründe kız, anne ve nineyi temsil etmektedir. Yüzyıllar boyunca Hristiyanlar arasında Kutsal Üçleme'nin simgesi haline gelmiş ve üç elementi temsil etmiștir. Hava, su, toprak veya sonsuz yaşam döngüsü: "Şekil 14." Günümüzde bu sembol mücevher tasarımı, amblem olarak karşımıza çıkmaktadır9.

Kendi teorisini Einstein ve Rosen'in teorisine dayanarak oluşturmuştur. Metinlerarasılık örneği olan bu sahnede Einstein ve Rosen'in isimleri anılarak teori anlatılmış, kişiler yüceltilmiş ve seyirci bilgilendirilmiştir.

Ulrich mağaranın içinde metal bir kapı bulur. Kapı zamanlar arası geçiş için kullanılmaktadır. Kapının üzerinde üçlü düğüm sembolü ve üzerinde "Sic Mundus Creatus Est” yazmaktadır. Bu söz Latince'de “Böylece Dünya Yaratıldı" anlamına gelmektedir. İnsan ve Evren adlı internet sayfasında şu bilgiler yer almaktadır:

\footnotetext{
“Zümrüt tablet Avrupa'lı okültist düşüncelerini dayandırdıkları kısa bir metindir. Yazılı ilk kaydına 800 yılında Abdulkadir Geylani'nin "Kitab-ı Sirr Al Asrar" (Sırların Sirrı) kitabında rastlanmaktadır. 14. Yüzyılda simyacı Ortolanus tarafından "Hermes'in Sirrı" adıyla şehredilen metin, bundan sonra simyanın gelişimi üzerinde etkili olmuştur."10
}

Tablet Hermetik yazılar içerisinde en önemlilerinden kabul edilmiștir. 11 kısa maddeden oluşan bir metindir: Dokuzuncu maddesi dizinin metal kapısı üzerinde kullanılmıștır. "Böylece Dünya yaratıldı." Bu da yeni bir metinlerarasılık örneği teşkil etmektedir. Ulrich kapıdan geçtiğinde sağa ve sola ayrılan iki ayrı tünel olduğunu görür. Kendi geldiği yönle beraber 3 ayrı yön vardır. Geçmiş, günümüz ve gelecek. Böylece Tannhaus'un teorisinin doğruluğu ispat edilmektedir.

Genç Egon iki cesetle ilgili adli tıpçıdan bilgi almaktadır. Adli tıpçı Erik'in dövmesine anlam verememiştir. Tekboynuz ya da Unicorn adlarıyla bilinen bu hayvan tek boynuzlu attır. Mitolojide kutsal olduğu, kanı içildiğinde ölümsüz kıldığına inanılmakta ve onu öldürenin lanetleneceği söylenmektedir. (İncil'de Geçen 10 Korkunç Canavar, Anonim, b.t.) Ölümsüz kıldığı bilinen bu hayvanın dövmesini, ölmüş Erik’te görmek ironi yaratmıştır. Tannhaus ve Jonas (Yabancı)'nın konuşmaları devam etmektedir. Yabancı Tannhaus'a daha önceki bölümlerde gördüğümüz kitabını göstererek Nietzsche'nin bengi dönüşü hakkında yazdığı yazıdan bahseder. Konu aslında 33 sayısına getirilecektir. Önceki bölümlerde de sık sık karşımıza çıkan 33 sayısının hayattaki önemi Tannhaus tarafından 
sıralamaktadır. Konuşmalarında Nietszche ve Dante'den bahsedilerek, yüceltme ve metinlerarasılık yapılmıștır.

Tannhaus ve Jonas'ın diyaloglarını günümüzde izlerken aralarda geçen tüm sahneler geçmişten gösterilmektedir. Böylece zaman-mekân algısı sürekli olarak kırılmaktadır.

Jonas'ın şeytandan bahsetmesinin hemen üzerine geçmişe dönülür ve papaz kostümü içerisindeki Noah'ı, kapağında üçlü düğümün baskısı olan defteriyle görürüz. Böylece Noah'ın kötü karakter olduğu bilgisini seyircinin düşünmesi istenir. Dizinin antagonist protagonist karşıtlılığı gizlenmiştir. Sezon sonunda antagonistin Jonas, protagonistin ise Noah olduğu düşünülmektedir. Nitekim Jonas solucandeliğini kapatmaya çalışırken, Noah elinde tarihlerin ve gidișatların yazdığı deftere bağlı kalarak insanları öldürme derdindedir. Noah dizideki 4 ailenin birbiriyle olan ilişkileri içerisinde listeye girmeyen tek kişidir. Ayrıca geçmiş, günümüz ve gelecekte hep aynı yaşta karşımıza çıkan tek karakterdir. Papaz kostümünün yıllar içinde hiç değișmemiş olması ișini kolaylaştırmaktadır.

Küçük Helge'nin gördügümüz ilk kötülüğü Claudia'nın köpeği Gretchen'e sopa atma oyunuyla mağarada kaybolmasını sağlamasıdır. Böylece zamanda yolculuk yapan ilk kişinin Erik değil bu köpek olduğu bilgisine ulaşılır. Gretchen isminin tercihi metinlerarasılık örneğini doğurmuştur. Gretchen ismi, Goethe'nin 1808 yılında yazdığı "Faust" adlı eseriyle popülerliğe ulaşmıştır. Kitaptaki Gretchen Faust'un sevgilisidir.

\section{Dogs of Berlin Dizisinde Postmodernist Bulgular: Bölüm 2 "Takım"}

$\mathrm{Bu}$ dizideki postmodern ögeler daha çok metinlerarasılık ve kimlik meselesi olarak yer almakla beraber kanun insanlarının ana akımdakinden farklı yorumlandığı sahnelere yer verilmiştir. 6 gün önce Çarşamba. Seiler emniyet müdürünün evine gider. Kapıyı açan çocuk ve Seiler arasında geçen diyalog sayesinde emniyet müdürünün eşcinsel evliliği yaptığı öğrenilmiş olur. Almanya'da 2017 yılında yürürlüğe giren "herkes için evlilik" yasasıyla beraber eşcinsel evliliği yasallaşmış ve bu duruma dizide yer verilmiștir. Sonraki bölümlerde de karşımıza çıkacak olan bu durum LGBTİ üyelerinin toplum içerisindeki kimlikleri ile var olabilmelerini göstermiștir, ki bu durum postmodernist toplum vurgusudur. LGBTİ bireyler devlet dairelerinde çalışmaktadır. Bu da erkek egemenliğinde görülen devlet işlerinin postmodern dünya düzeni ile değiştiğini göstermektedir. Seiler emniyet müdürünün yanına geldiğinde kadınların kürek çekmesi kendisinin ise küçük taburede aralarına konumlandırılması üstünlüğün bir anlatısını oluşturmaktadır: "Şekil 15"

İlerleyen sahnelerde Eva anne ve babalarına haber vermeden torunlarını okuldan alır. Çocukların sırayla kaydıraktan kaydığını gören Eva, duruma müdahale eder. Sırada bulunan ve Alman olmayan çocukları kovalamıştır. Torunlarının tepkileri postmodernist bir durum olan çok kültürlülük örneği oluşturmaktadır.

Eva: Niye siz kaymıyorsunuz? Bu ülke bizim! Almancılara hakkınızı yedirmeyin sakın... Emilia: Ama sırada onlar vardı. Biz sıraya girmiştik.

Eva: Soyu bozuklar! Hadi şimdi siz kayın. Hadi!

Emilia: İnsanlara soyu bozuk deme! (Dogs of Berlin, 1. Sezon, Bölüm 2: 34:13-34:46)

Raif ve Murad'ın içinde bulunduğu metroda canlı müzik yapılmaktadır. Bir genç kemanıyla Antonio Vivaldi'nin ${ }^{11} 4$ Mevsim adlı eserinden Bahar'ı çalmaktadır. Murad çalınan kemana doğaçlama şarkı söyler. Vivaldi'nin eserinin çalınması metinlerarasılık örneği oluşturmaktadır. İlk bölümde Türkiye-Almanya maçına bahis oynayan Kurt, Orkan maça 
çıkmasa bile Almanya'nın kazanabileceğini öğrenmiştir. Her bölümde kendi çıkarları uğruna hareket eden Kurt yine öyle davranır. Almanya takımının hazırlık odasına gider ve oyuncuların moralini bozmak için Orkan Erdem'in öldürüldügünü söyler. Böylece oyuncuların motivasyonunu kırar. Polisliğin kabul görmüş tanımından farklı bir kodlama ile postmodernizm vurgusu yapılmaktadır. Ana akımda güç temsili, sağduyulu ve iyi insan olmak zorunda olan polis bu sahnede ve dizinin tamamına yakınında tam tersi yönde ilerlemektedir. Polisler çıkarlarına göre hareket eden, seçtiği yönlerde duygularının daha ön planda olduğu kişilerdir.

\section{Bölüm 4 "Kolay Maç"}

Erol eski ekip arkadaşını ziyarete hastaneye gitmiştir. Kadın Erol'un maskesini görünce onu Zorro'ya ${ }^{12}$ benzetir. Zorro Kaliforniya yerlilerini zalimlerden koruyan maskeli bir karakterdir. Yetkililerin beceriksizlikleri sonucu yakalanamayan kişileri yakalamaktadır. Maskesiyle kimliğini gizleyen Zorro silahlarda da uzmandır. (Wikipedia, b.t.). Bu karakter polislerin silahlı olmaları, kötüleri yakalamaları ve kimliğini çok belli etmemeleriyle bağdaştırılmış ve metinlerarasılık yapılmıştır: "Şekil 16"

Raif ve Murad'ın çatıdaki sahnesinde metinlerarasılık örneği ile karşılaşılmaktadır. Metinlerarasılık Quenns of The Stone Age adlı müzik grubunun albüm kapağı ile yapılmıştır: "Şekil 17". Villains adlı albümünün kapağı duvara işlenmiş ve sahnede dekor olarak kullanılmıștır. Quenns of The Stone Age altenatif ve hard rock türünde müzik yapan bir gruptur.

Sahnenin devamında Eko Fresh $^{13}$ ve Kool Savaş ${ }^{14}$ isimleri geçmekte ve bu isimler yüceltilmektedir. Raif Murad'ı rap müzik yapması konusunda cesaretlendirmek için bu isimlerden faydalanmıştır. Sahnede Eko Fresh'in Kool Savaș'in konserinde sahneye çıkması ile ünlü olduğu anlatılmaktadır. Eko Fresh ilk albümünü Kool Savaş'ın desteği ile çıkartmıştır. Müzisyenlerin anlatılması ve onların yolundan gitmeleri gerektiğini düşünüyor olmaları ile yüceltme yapılmıștır. Böylece metinlerarasılık örneği doğmuştur. Metinlerarasılık Haftbefehl' $i^{15}$ konser videosunun izlenmesi ve Xatar ${ }^{16}$ adının anılması ile devam etmektedir: "Şekil 18".

İlerleyen sahnelerde Maissa eve imam çağırmıştır. Murad'ın imamla konuşmasını ister. Maissa Murad'ın rap müzik ve asi arkadaşları için liseyi bitiremeyeceğinden korkmaktadır. Aralarında geçen diyaloglarda metinlerarasılık ile karşılaşılmaktadır:

Maissa: Rapçi olmak isteyen çok çocuk var.

Murad: Get Rich or Die Tryin'. (Dogs of Berlin, 1. Sezon, Bölüm 4: 39:39-39:42).

Murad'ın Get Rich or Die Tryin' (Zengin Ol ya da Ölmeyi Dene) demesi ile 50 Cent'e gönderme yapılmaktadır. 50 Cent'in solo albümünün adı olan Get Rich or Die Tryin' 2005 yılında Jim Sheridan tarafından çekilen filme de adını vermiştir ve 50 Cent filmin başrolünü üstlenmiştir. Bir başka metinlerarasılık örneğine Paula'nın dükkânına haraç mafyasından Murathan geldiğinde rastlanmaktadır. Aralarında geçen diyalog şu şekilde özetlenebilir:

Murathan: Sevdiğim bir karakteri andırdığın için senden hoşlandığımı söyledim.

Paula: Ya? Hangisi?

Murathan: Dirty Dancing'teki Baby. (Dogs of Berlin, 1. Sezon, Bölüm 4: 44:34-44:39).

Dirty Dancing (1987) filmindeki Baby karakteri Frances "Baby" Houseman adıyla rol alan Jennifer Grey'dir. Murathan Paula'nın dükkânından çıkarken filmin müziği olan The 
Time of My Life (Hayatımın Zamanı) adlı şarkıyı telefonundan çalar ve eşlik eder. Sahnede filmden, başrolünden ve müziğinden bahsedilmiş ve böylece film yüceltilmiștir.

\section{Bölüm 10 “Zafer Kutlaması”}

Bölüm metinlerarasılık örnekleriyle başlamaktadır. Metinlerarasılık Marie von EbnerEschenbach ${ }^{17}$ ve Yoda'nın ${ }^{18}$ sözleriyle yapılmıştır.

Marie von Ebner-Eschenbach: "Özgür iradeye inananlar daha önce ne aşık olmuştur ne de birinden nefret etmiștir."

Yoda: "Korku, öfkeyi; öfke, nefreti; nefretse acıyı doğurur."

Kurt, Erol'la konuşmuş ve muhbire gerek olmadığını, her köşeden izlendiklerini söylemiştir. Ekip üyelerinin olayı durdurmaya çalışmaları ve Erol'un Kurt'la beraber ekibin başında yer alması LGBTİ üyelerinin toplum içerisindeki kimlikleri ile var olabilmeleri durumunu göstermiștir ki bu durum postmodernizm vurgusudur.

Kareem Tarık-Amir'in elinde Kurt'un oynadığı bahis bileti vardır. Kurt'u bu biletle tehdit ederek; evine bir operasyon düzenlemesini ve abisini içeri atmasını ister. Sonraki bahis işlerinde de Kurt'un kendisine yardım etmesi karşılığında ona ödemeye yapacağını ve ancak o sayede biletin medyaya çıkmayacağını söyler. Kurt, Erol'u yanına çağırır ve daha önceden bulup gizlediği Lamborghini'yi getirir. Orkan Erdem cinayeti ve Tarık-Amir çetesi olaylarını birbiriyle alakalı hale getirmek için Lamborghini'yi temizleyip, içine Kareem'in parmak izleri olan bir beyzbol sopası yerleștirirler. Tüm bu sahte deliller ana akımda yer alan polis kimliğiyle ters düşmektedir. Kurt, kendi bahis bileti ortaya çımasın diye çıkarları uğruna Kareem'le işbirliği yapacak gibi davranmaktadır. Erol ise peşinden uzun zamandır koștuğu Tarık-Amir çetesine karşı olan nefretinden dolayı Kurt'la işbirliği yapmaktadır. Kurt, farklı bir telefon hattından sesini değiştirerek Lamborghini'yi bulduğunu söyler. Daha sonra olay yerine gitmiş gibi davranırlar. İlerleyen sahnelerde Tarık-Amir'lerin evine yapılır. Kurt, yanında bulunan kokaini Kareem'in dairesine yerleştirir ve onu tutuklar. Biletin Kareem'in odasında olması ihtimaline karşı odayı ateşe vererek suç mahallini bozar. Ana akımda yer alan "doğrunun ve adaletin peşinde" olan polisler burada kendi çıkarlarının peşindedir ve bu farklı kodlama postmodernizm vurgusudur.

Erol babasını eve yemeğe davet etmiștir. Cinsel kimliğinden ötürü oğluyla görüşmeyen baba evi incelemektedir. Erol ve sevgilisinin fotoğrafını ters çevirmiş, buzdolabındaki içkilere tepki göstermiştir. Konuşmalardaki çelişki postmodern kimlik meselesi örneğidir.

Baba: Ben Allah'ın yolundayım oğlum tamam mı?

Erol: ... Bir gün herkesten dindarsın, öbür gün umrunda bile değil! ... (Dogs of Berlin, 1. Sezon, Bölüm 10: 46:24 - 47:53)

Erol'un ağlama sahnesinin üzerine Moby'nin"19 “The Dogs" şarkısı çalmaya başlamış ve karakterlerin görüntüleri eş zamanlı olarak verilmiştir. Bu şarkının kullanımıyla metinlerarasılık yapılmıştır.

\section{Perfume Dizisinde Postmodernist Bulgular: Bölüm 2 "Skatol”}

$\mathrm{Bu}$ dizideki postmodern ögeler daha çok metinlerarasılık olarak yer almakla beraber kanun insanlarının ana akımdakinden farklı yorumlandığı sahnelere yer verilmiştir.

Birinci bölüm kilisede Moritz ve Butsche'nin kavgasıyla bitirilmiştir. Bu bölümün başında Moritz iki farklı mekânda gösterilmiștir ve sonunda yeniden kilisedeki kavgalarına 
dönülmüştür. İlk bölümün sonunun gösterilmesi ve olay akışının bu şekilde devam etmesiyle zamanda kırılma yaratılmıștır.

Butsche'nin gençken kilisede görev aldığı ve dua ettiği görülmektedir: "Ey Mecdelli Meryem20, dualarını esirgeme benden. Benim için sen, azizelerin en güzelisin. Gerçek sevginin ne olduğunu bilen tek azize sensin..." Butsche'nin azizelerden Meryem'i seçip ona dua etmesi ironiktir. Meryem'le ilgili bilgilerde bir kokudan bahsedilmektedir. Vikipedi'de geçen bilgi şu şekildedir: "Luka İncili'ne göre İsa bir gün Farisilerden Simun〉un evine yemeğe gider. Yemek esnasında kentte günahkâr olarak bilinen bir kadın odaya girer ve İsa`nın ayaklarını gözyaşları ile ıslatıp saçları ile siler. Daha sonra güzel kokulu bir yăg ile ovar. Simun, «Bu adam peygamber olsaydı, kendisine dokunan bu kadının kim ve ne tür bir kadın olduğunu, günahkâr biri olduğunu anlardı," der. İsa Simun'a kısa bir öykü anlatır ve sonrasında kadının diğerlerinden çok olan günahlarını bağışladığı için onun da kendisini diğerlerinden daha çok sevdiğini söyler. Daha sonra kadına "Günahların bağışlandı... İmanın seni kurtardı, esenlikle git," der. Luka İncili'nde bahsedilen bu günahkâr kadının Mecdelli Meryem olduğu kabul edilir.21"

Genç Butsche'nin kilisedeki görüntüsünden günümüzdeki haline kesme yapılmış ve mekân olarak yine kilisede konumlandırılmıştır. Dizide çok kez görülecek olan zamanmekân algısını kırmanın bir örneği daha böylece gerçekleşmiştir: "Şekil 19."

Grünberg eve geldiğinde karısı Elisabeth kitap okumaktadır. Grünberg'in, ne okuduğunu sormasıyla metinlerarasılık örneği oluşmaktadır. Öncesine kadar seyirci kitabın ne olduğu konusunda bilgisizken kadının cevabıyla Anna Karanina ${ }^{22}$ olduğu öğrenilir. Anna Karanina romanında dürüst evliliğin ve yasak ilişkinin karşılaştırılmasının yapılmış olması sahne için çok uygundur. Kadının kocasına karşı olan şüphesi kitapla desteklenmektedir. Nadja, Grünberg'i şahsi telefonundan yeniden arar, ancak Grünberg cevap vermez. Elisabeth şüpheyle bakmaya devam etmektedir. Bunun üzerine gelen diyaloglardan anlaşılacağı gibi Grünberg karısının kendisinden şüphelendiğini anlamıştır.

Grünberg: İnsan, kitapçı raflarında bir iki hafta kalan “çok satan”ları da keyifle okur. Ama eninde sonunda her zaman klasiklere döner. Her zaman. Gerçek aşk budur.

Elisabeth: Sonun cehennem olacak senin Grünberg. (Perfume, Bölüm 2: 30:45-31:08)

Yeniden geçmişe dönüldügünde Roman, Butsche ve Moritz'in Elena'yla tanışma anları gösterilir. Elena gençlerin takıldıkları Horo Kalesi'nde dergi okumaktadır. Önceki sahnede olduğu gibi burada da "Ne okuyorsun?" sorusu sayesinde okunanın ne olduğunu seyirci öğrenir. "Vampir Avcısı" cevabıyla yeni bir metinlerarasılık örneği görülmektedir.

Nadja'nın Savcı Grünberg'in tüm engellerine rağmen Horo Kalesi'nde köpeklerle çalışması ve Katharina'yla aynı şekilde öldürülmüş bir köpek bulmasıyla bölüm bitirilmiştir. Böylece bölüm sonunda kadın profil uzmanı Savcı karşısında üstünlük kazanmıştır.

\section{Bölüm 3 "Sentez"}

Butsche dışarda gördüğü küçük kızın yanına gider. Kız bahçede duran teknenin içindedir. Teknenin adı "ODIN" olarak görünmektedir: "Şekil 20." Bu bir metinlerarasılık örneğidir. Odin büyük İskandinav tanrılarının oluşturduğu soyun lideri olmakla beraber yaşadığı Asgard'daki insanları yönetir. Kendisi de ölümlüdür. Butsche'nin genelev işletmesi ve oradaki kadınların onun sözünden çıkmamalarıyla bağdaştırılabilir. Butsche bununla övünmektedir. Başka bir metinlerarasılık kıza adını sorduğunda ortaya çıkar. Kız "Angelina Jolie" demiştir. Angelina Jolie'nin güzelliğiyle kendisini bağdaştırmış ve onu yüceltmiştir. 
Önceki bölümde “Mecdelli Meryem'e dua ettiği görülen Butsche bu bölümde geçmişte bir sahnede "Maria Magdalena" şarkısını söylerken gösterilir. Aynı metinlerarasılık burada da karşımıza çıkmaktadır: "Şekil 21."

Nadja ve Matthias Karl'ın evine gelmiş Elena'nın odasını aramaktadırlar. Nadja Elena'nın yatağının altında bir kitap bulur. Seyirci kitabın ne olduğunu öğrenemeden zaman kırılır geçmişe gidilir. Aynı kitap Genç Elena'nın elindedir. Kitabın ne olduğu önceki bölümlerde olduğu gibi "Ne okuyorsun?" sorusunun cevabında öğrenilir. Bulunan kitap Koku'dur. ${ }^{23}$ Dizinin bu kitabın uyarlaması olması sebebiyle kitabın gösterilmesi yüceltme görevi görmüştür. Nadja'nın kitabı okuma sesi bu sahne üzerine bindirilmiştir. Nadja kitaptan birkaç cümle okumuşken onun sesi üzerine Elena'nın sesi bindirilir ve Elena'nın gençlere kitabı okuduğu gösterilir. Böylece sahnede hem zaman-mekân kırılmış hem de metinlerarasılık yapılmıștır: "Şekil 22."

Nadja: Bahsettiğimiz dönemde şehirlerde biz modern erkek ve kadınların hoşuna gitmeyebilecek bir koku vardı. Sokaklar gübre, avlular sidik ve merdivenler çürümüş tahtayla fare boku kokuyordu.

Elena: Mutfaklar bozulmuş lahana ve koyun yağı havasız salondaki toz öbekleri bayat yatak odaları da yağlı çarşaf, rutubetli kuş tüyü yatak ve mayhoş lazımlık kokuyordu. (Perfume, Bölüm 3: 39:27 - 40:07)

\section{Bölüm 5 "Kalp Notaları"}

Nadja "Koku"24 filmi karşısında uyuyakalmıştır. Bilgisayarın ekranında Grenouille'in bir kadına saldırdığı an durdurulmuştur: "Şekil 23." Metinlerarasılık olarak görünen bu kare aynı zamanda uyarlaması yapılan kitabın daha önce yapılmış başka bir uyarlamasıdır. Kendinden önce yapılana saygı sunulmuştur. Sonraki sahnelerde Nadja'nın filmi izlediği Grenouille'in eline sürdügü parfümle bir köpeği kendisine çektiği sahne izleyici ile paylaşılmıştır. Nadja film ve kitaptaki; köpeğin takip bölümünü incelenmesi sonucu buldukları ölü köpekle bir bağ kurmuștur.

Butsche'nin müdüre yazdığı mektup işe yaramamıș ve onun okuldan atılmasını sağlayan Roman'dan intikam almak istemiştir. Elini kirletip Elena'nın alnına leke sürmüş ve Roman'dan intikamını bu şekilde alacağını belirtmiștir. Butsche'nin bu hareketi sonucu metinlerarasılık görülmüştür. Seyirci "Alnına kara sürmek", "Alnına kara leke sürülmesi" deyimi gibi sözleri hatırlamıștır. Elena'nın Roman ve Butsche'nin arasındaki gerilimle bir alakası olmadığı halde Butsche intikamını onun üzerinden almaya karar vermiştir. Nadja Koku Merkezi'ne gidip bilgi almaktadır. Görevli kiși ona "Süskind'in Grenouille karakteri en çok kızıl saçlıları arzulardı." der. Böylece uyarlaması yapılan eserin yaratıcısından bahsedilmesi ile metinlerarasılık örneği doğmuştur. Yaratıcının adı kullanılarak ustaya saygı gönderilmiştir. Ayrıca seyirci eser hakkında yeni bir bilgi almıştır.

\section{Sonuç}

Televizyon, yalnızca kendi geçmişini de içeren, hayal etme, hatırlatma, gösterme veya tekrarlama kapasitesi nedeniyle değil, aynı zamanda bir ortam ması nedeni ile de önemli bir rol oynamaktadır. Televizyon her şeyi hafızasında tutamaz ve tüm yayınları da arşivleyemez. Sonuç olarak nostalji ile yakından ilişkili olan eskiye dönüş ve eskiye dönüşteki ilgili kavramlar olan metinlerarasılık, pastiş gibi kavramlar kaçınılmaz hale gelir. Bu anlamda televizyon, geçici bir alan arasında dolaşan karmaşık bir zaman makinesi gibi konumlanmaktadır. Şimdiki zaman, bilinmeyen bir gelecek ve geçmiş zamanlar. 
Bu çalışmanın iddiası; yeni dönem izleme platformlarında yer alan Alman yapımlarında yer alan kanun insanları profilinin ana akımdan farklılıklar gösterdiğidir. Bu kapsamda çalışmada, Dark (2017), Dogs of Berlin (2018), Perfume (2018) dizileri incelemeye alınmıştır. $\mathrm{Bu}$ dizilerin üzerinden postmodern ögeler ile olan ilişkisi tartışılmaktadır. Diziler, postmodernist kişi-karakter yansıması çerçevesinde incelenerek geçmiş dönemdeki kanun insanı profilleri ile karşılaştırılmaktadır.

Dark, Baran Odar yönetmenliğinde 2017 yılında çekimine başlanmış, Alman yapımı ve Netflix'te yayınlanan bir dizidir. Dizinin ana konusunu "kaybolan bir çocuğu arayış serüveni” olarak özetlemek mümkündür. Geçmiş, günümüz ve gelecek sahnelerinin paralel kurgu kullanılarak hazırlandığı dizide; çocuğun bulunmasıyla görevli olan polis Ulrich'in, kendi çocuğu kayboluncaya kadar olayla çok fazla ilgilenmediği görülmektedir. Dizide yer alan postmodern ögelere genellikle metinlerarasılık, nostalji ve zamanmekan kırılması şeklinde rastlanılır. Dogs of Berlin, Christian Alvart yönetmenliğinde 2018 yılında çekimine başlanmış, Alman yapımı ve Netflix'te yayınlanan bir dizidir. Dizinin ana konusunu "cinayet masasında ve narkotik büroda görev yapan iki polisin aynı davaya verilmesi ve futbolcu olan Orkan Erdem cinayetinin çözülmeye çalışmaları" olarak özetlemek mümkündür. Öldürülen futbolcunun Türk olması sebebiyle narkotik büroda görev yapan Türk polis Erol Birkan, davaya getirilir. Dizide postmodern ögeler: metinlerarasılık ve kimlik meseleleri şeklinde verilmektedir. Çalışmada örnekleme dahil edilen üçüncü dizi olan Perfume, Philipp Kadelbach yönetmenliğinde 2018 yılında çekimine başlanmış, Alman yapımı ve Netflix’te yayınlanan bir dizidir. Perfume Patrick Süskind'in "Das Parfum" (1985) adlı romanından uyarlanmıștır. Dizinin ana konusunu "peşpeşe gelen, maktullerin koku bezlerinin vücutlarından ayrıldığı ve saçlarının kesildiği cinayetleri çözmek için profil uzmanı, savcı ve polislerin çalışmaları" olarak özetlemek mümkündür. Seyirci kanun insanları ve profil uzmanı olan Nadja ile savcı Grünberg'i ilk olarak yasak ilişkileriyle tanır. Dizide postmodern ögeler: metinlerarasılık ve zamanmekân kırılması olarak kullanılmıştır.

Söz konusu bu üç Alman dizisi, sermaye kültürünün eleştirel biçiminde geleneksel kalıpların dışına çıkmaktadır. Sosyal ilişkiler hakkındaki varsayımlar, televizyonun inşa etmeye ve arabuluculuk yapmaya yardımcı olduğu meta kültürüne dayanır. Bu üç dizi de anlatı, liderlik, siyasi güç gibi kavramlara meydan okumaktadır. Başka bir deyişle, politik güç hem hayal edilmekte hem de tüketici tarzı konularına indirgenmektedir. Bununla birlikte incelenen dizilerde nostalji, pastiş, metinlerarasılık az ya da çok gerçekçi olmayan bir şekilde olumlu ya da olumluya yakın duygularla canlandırmaktadır. Bu noktada, genel olarak bu üç Alman dramasının özellikle nostalji ile daha karmaşık bir ilişki içerisinde oldukları söylenebilir. Bu üç dizinin, seyircinin özleminin nesnesi olduklarını ve aynı zamanda, izleyicinin bir televizyon dizisi için birden fazla düzeyde ilgilenmesi için birden fazla nedeni olduğunu göstermektedir.

En çok tercih edilen postmodern türlerin parodi, pastiş, metinlerarasılık ve nostalji olduğunu düşünüldüğünde, incelemeye alınan üç Alman dizisinin postmodern estetik ile gerilim ${ }^{25}$ arasındaki ilişki açısından, gerilimin ve dedektif anlatıların (modernizm) popüler yüzeylerini metinlerarasılık özelliği ile harmanlayarak, bu dizilerin cazibesini ve çekiciliğini polisiye anlatısı ile zenginleștirildiği görülmektedir. Gerilimin katkısının, suç anlatılarında, avangard sonrası dönemde çok önemli olduğunu düşünüldügünde, bu diziler bunu da başarmaktadır. 
Söz konusu dizilere postmodern kişi-karakter yansıması olarak bakıldığında "kanun insanı profili"nin ana akımda yer alan; kabul görmüş şeklinden farklı kodlandığı görülmektedir. Kanun insanları "güç temsili, sağduyulu, iyi insan" kavramlarından çok "aldığı kararlarda duygularının önemli rol taşıdığı, suç işleyen ve çıkarcı" gibi durumları da kapsayacak șekilde yeniden şekillendiği görülmektedir.

\section{Notlar}

1 Serttaş ve Gürkan (2015) reality şovlar ile ilgili olarak çalışmalarında, Gerçeklik Televizyonu terimini kullanmışlardır. Bu çalışmada da bundan sonra Gerçeklik Televizyonu terimi kullanılacaktır.

2 Albert Einstein (1879-1955) Nobel Fizik Ödülü sahibi Yahudi asıllı Alman teorik fizikçi.

3 Harry Houdini (1874-1926) Asıl adı Erik Weisz. Macar asıllı Amerikalı illüzyonist. Kapatıldığı, bağlandığı yerlerden kurtulma numaralarılya ünlüdür.

4 Hansel ve Gretel. Grimm Kardeşler ve onlardan önce Giambattista Basile tarafından uyarlanan masal. Masaldaki cadı Hansel'i şişmanlatıp yemeyi planlamaktadır (http://snowwhiteandredapple.blogspot.com/2012/07/, Erişim Tarihi: 15 Mayıs 2019)

5 Ayrıntı için bknz.: Tanrım Beni Yavaşlat (Hitit Duası) https://www.turkishnews.com/tr/content/2016/11/18/tanrim-beniyavaslat-hitit-duasi/, Erişim Tarişhi: 15 Mayıs 2019.

6 Ayrıntı için bknz.: Tears for Fears https://en.wikipedia.org/wiki/Tears_for_Fears, Erişim Tarihi: 17 Mayıs 2019.

7 Mudra bir duruş, ellerin mistik tutuşu, bir mühür ya da bir sembol olarak tanımlanmaktadır. (Gürsözer, 2009)

8 Captain Future uzay yolculuğu yapan bilim kurgu kahramanı.

9 Ayrıntı için bknz.: Teslis, https://tr.wikipedia.org/wiki/Teslis, Erişim Tarihi: 20 Mayıs 2019

10 Ayrıntı için bknz.: Zümrüt Tabletteki Sırların sırrı, http://aasmaestefan.blogspot.com/2014/12/zumrut-tabletteki-srlarnsrr.html, Erişim Tarihi: 25 Mayıs 2019.

11 Antonio Vivaldi (1678-1741) italyan barok klasik müzik bestecisi.

12 Asıl adı Senor Zorro olan 1919 yıında Johnston McCulley tarafından yaratılan kurgusal karakter.

13 (Ekrem Bora) Türk asıllı Alman rapçi.

14 (Savaş Yurderi) Türk asıllı Alman rapçi.

15 (Aykut Anhan) Kürt asıllı Alman rapçi.

16 (Giwar Hajabi) Kürt asıllı Alman rapçi.

17 Marie von Ebner-Eschenbach (1830-1916) Avusturalyalı yazar.

18 Yoda: Büyük Jedi UstasI: George Lucas tarafından yaratılan Yıldız Savaşları filminin kurgusal karakteri.

19 Moby sahne ismini kullanan Richard Merville Hall (1695 - Günümüz) Amerikalı müzisyen, yazar.

20 Mecdelli Meryem (Magdalalı Meryem): Yeni Ahit'e göre İsa'nın takipçilerinden biri. Markos ve Yuhanna İncil'lerine göre, gömüldükten sonra dirilerek İsa'yı gören kişi (ïncil-Tevrat-Zebur, https://incil.info/kitap/Yuhanna/20, Erişim Tarihi: 1 Haziran 2019).

21 Ayrıntı için bknz.: Mecdelli Meryem, https://tr.wikipedia.org/wiki/Mecdelli_Meryem, Erişim Tarihi: 30 Mayıs 2019.

22 Lev N. Tolstoy tarafından yazıımış 1877 'de yayınlanan roman.

23 Patrick Süskind tarafından 1985 yılında yazılan Dünya Fantezi Ödülü sahibi kitap.

24 Patrick Süskind'in aynı adlı eserinden uyarlanan yönetmenliğini Tom Tykwer'in yaptığı 2006 yapımı film.

25 Bu diziler polisiye unsurlar taşıdıkları için anlatıları gerilim özellikleri de taşımaktadır. 


\section{Kaynakça}

Akay, A. (1992). Postmodern Konumdaki Filozoflar. Defter. 18.

Büyükdevenci, S. ve Öztürk, S. R. (1997). Postmodernizm ve Sinema. Ankara: Ark Yayınları.

Erdem, Y., ve Mustafa Çağlayandereli. (2006). Televizyon ve Gençlik: Yerli Dizilerin Gençlerin Model Alma Davranışı Üzerindeki Etkisi, C.Ü. Sosyal Bilimler Dergisi, $30(1)$.

Foster, P. (1989). Improving the doctor-patient relationship: a feminist perspective, Journal of Social Policy, 18, 3.

Gordon, A.B. (2008). Conspiracy Theory in Film, Television, and Politics. London: Praeger.

Günay, D. (2003). Metin Bilgisi. İstanbul: Matbaa 70.

Gürkan, H. (2012). Postmodernism and Cinema: Postmodern Discourse in the Movie of David Lynchs “Blue Velvet”. Akdeniz İletişim Dergisi. Sayı 17: 102-111.

Hodges, L. (2008). Genre, Hybridity, and Postmodernism in The X-Files, The Essential Science Fiction Television Reader içinde, ed. J.P.Telotte, The University Press of Kentucky.

Ispir, N. ve Zekeriya K. (2011). Sinemada Postmodern Arayışlar. Atatürk İletişim Dergisi. Sayı 2: 81-99.

Jameson, F. (1991). Postmodernism, or the Cultural Logic of Late Capitalism, Durham, NC: Duke University Press.

Karaburgu, O. (2008). "Arayışın Postmodernist Anlatısı: Bin Hüzünlü Haz." Sözlü Bildiri. 1980'den Sonra Türk Romanı Sempozyumu. Kayseri: 27-28 Mart 2008.

Lembo, R. (2003). Thinking through Television. Cambridge: CUP.

Mutlu, E. (1999) Televizyon ve Toplum, TRT Yayınları, Ankara.

Özdemir, M. (2007). Nitel Veri Analizi: Sosyal Bilimlerde Yöntembilim Sorunsali Üzerine Bir Çalışma. Eskişehir Osmangazi Üniversitesi Sosyalbilimler Dergisi. 11 (1): 323343.

Priest, S. (1996). Doing Media Research: An Introduction. Thousand Oaks, CA: Sage. Ramasubramanian, Srividya (2005) A Content Analysis of the Portrayal of India in Films Produced inthe West. The Howard Journal of Communication 16 (4).

Serttaş, A., Gürkan, H. (2015). Türkiye'deki Kadın İzleyicilerin Televizyon Programlarındaki Kadını Alımlaması, İstanbul Üniversitesi İletişim Fakültesi Dergisi, I: (48).

Sim, S. (2006). Postmodern Düşüncenin Eleştirel Sözlüğü, (Çev: Mukadder Erkan, Ali Utku) Ankara: Ebabil Yayınları.

Tanrıöver, H. U. (2010) Türkiye'de Film Endüstrisinin Konumu ve Hedefleri, İTO Yayınları, İstanbul.

Tudor, D. (2012). Selling Nostalgia: Mad Men, Postmodernism and Neoliberalism, Society $49(4)$ 


\section{İnternet Kaynakları}

İncil-Tevrat-Zebur, https://incil.info/kitap/Yuhanna/20, Erișim Tarihi: 1 Haziran 2019

Johann Wolfgang von Goethe, https://tr.wikipedia.org/wiki/Johann_Wolfgang_von_ Goethe, Erişim Tarihi: 25 Mayıs 2019)

Mecdelli Meryem, https://tr.wikipedia.org/wiki/Mecdelli_Meryem, Erişim Tarihi: 30 Mayıs 2019.

Once upon a Time, http://snowwhiteandredapple.blogspot.com/2012/07/, Erişim Tarihi: 15 Mayıs 2019

TanrımBeniYavaşlat:HititDuasıhttps://www.turkishnews.com/tr/content/2016/11/18/ tanrim-beni-yavaslat-hitit-duasi/, Erişim Tarişhi: 15 Mayıs 2019.

Teslis, https://tr.wikipedia.org/wiki/Teslis, Erişim Tarihi: 20 Mayıs 2019

Zümrüt Tabletteki Sirların sırrl, http://aasmaestefan.blogspot.com/2014/12/zumruttabletteki-srlarn-srr.html, Erişim Tarihi: 25 Mayıs 2019

\section{Ekler}

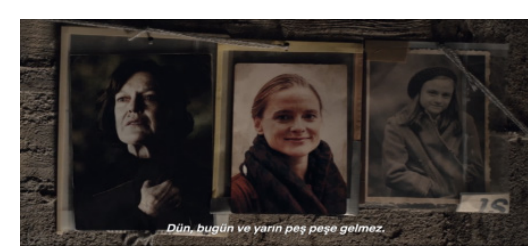

Şekil 1: A. Einstein'in sözünü destekleyici anlatım

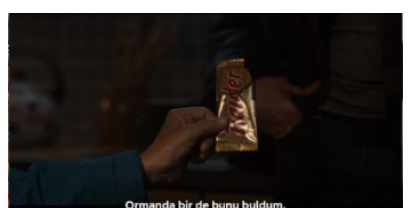

Şekil 3: Nostalji unsuru Raider çikolata

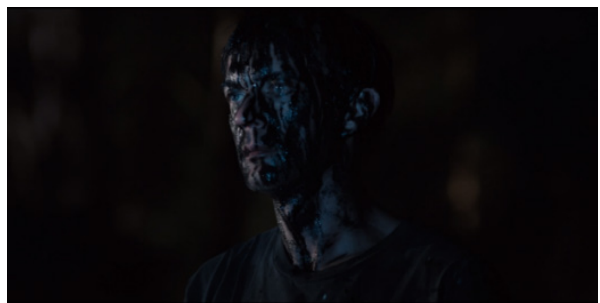

Şekil 5: Michael ve Hamlet arasındaki bağlantı

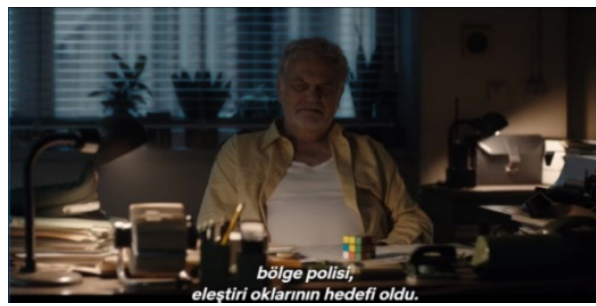

Şekil 7: Rubik küpü

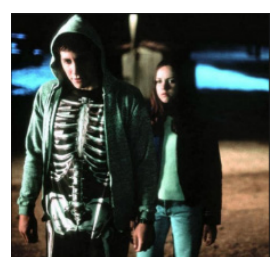

Şekil 2: Donnie Darko (2001)

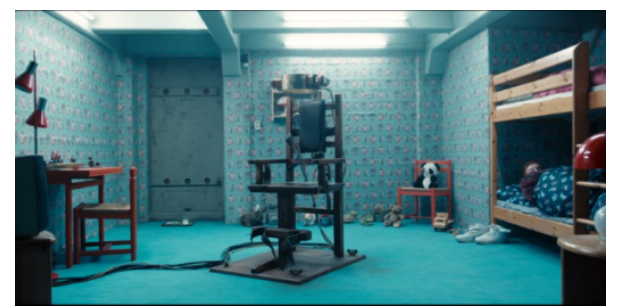

Şekil 4: Nostalji unsurlarıyla bezenmiş mekan

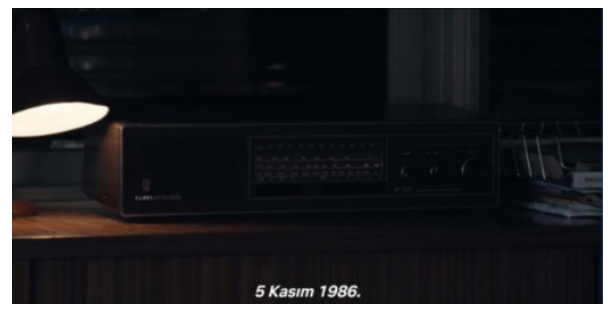

Şekil 6: Grundig RF 425 marka radyo

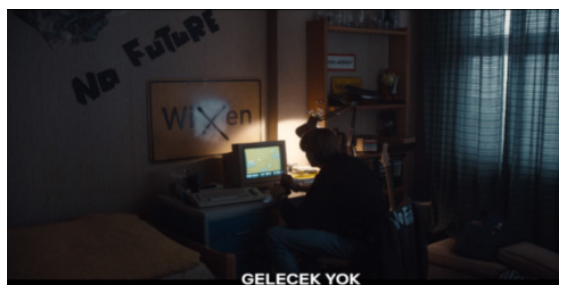

Şekil 8: Gelecek yok sloganı 1 


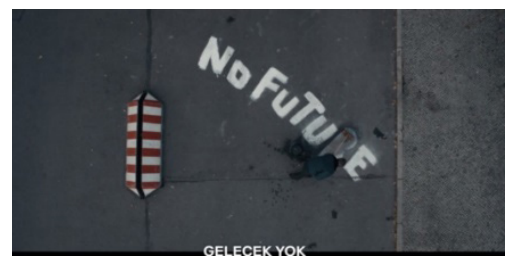

Şekil 9: Gelecek yok sloganı 2

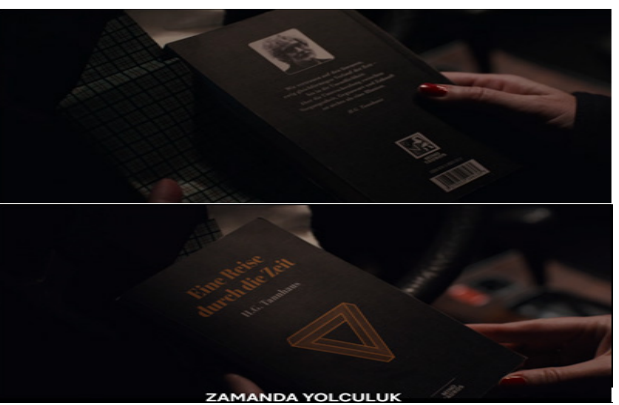

Şekil 11: Yunan mitolojisine gönderme

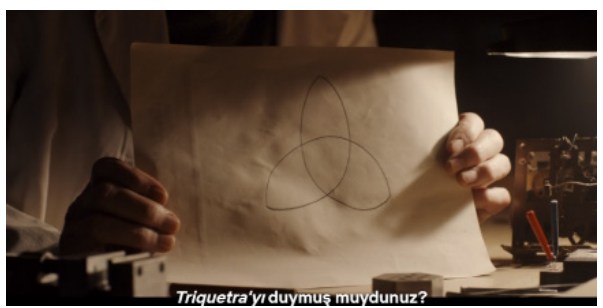

Şekil 13: Triquetra çizimi

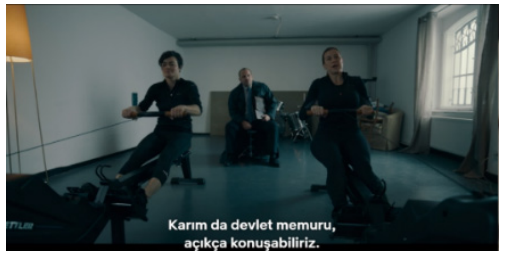

Şekil 15: LGBTI üyelerinin toplum içerisindeki kimlikleri

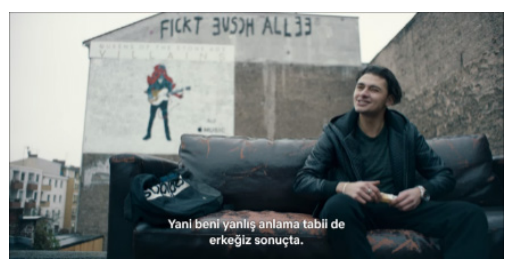

Şekil 17: Villains albüm kapağı
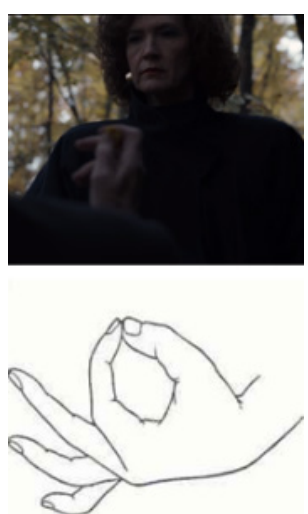

Şekil 10: Mudra örneği

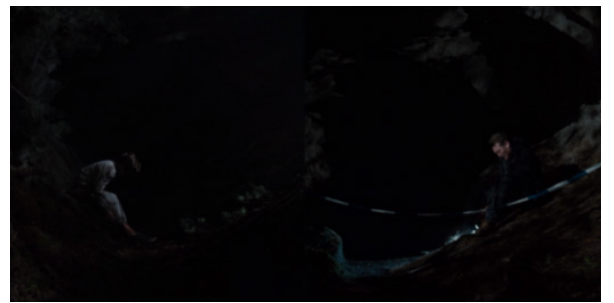

Şekil 12: Zaman-mekan algısının kırılması
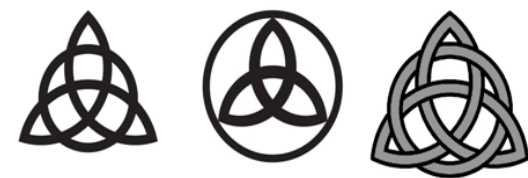

Şekil 14: Triquetra sembolleri

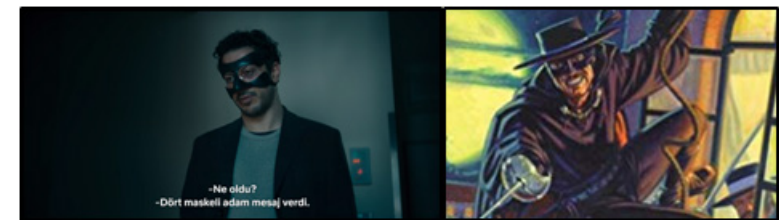

Şekil 16: Polisin Zorro ile bağlaştırılması

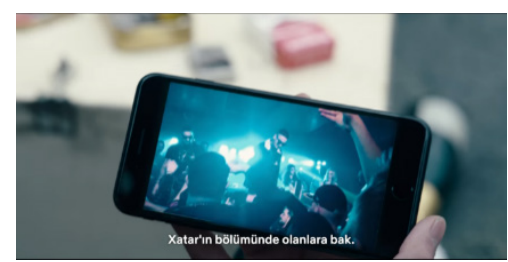

Şekil 18: Haftbefehl Hamburg konseri. 


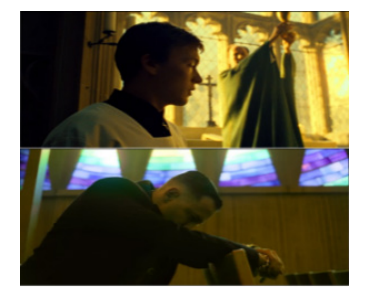

Sekil 19: Zaman-mekan algısının kırılması örneği

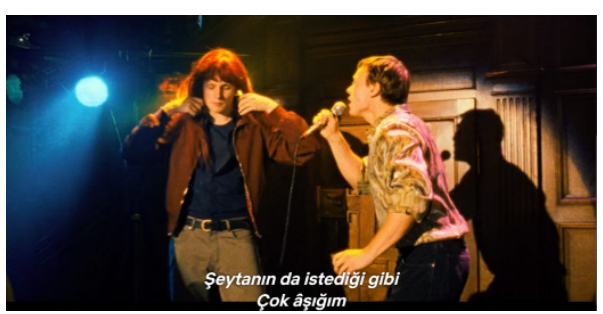

Şekil 21: Maria Magdalena şarkısı

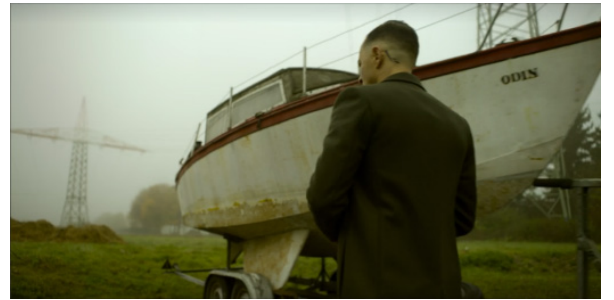

Şekil 20: Odin'e gönderme yapılması

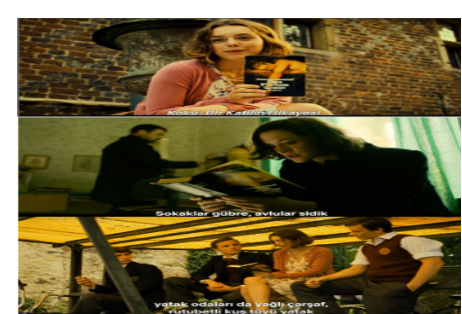

Şekil 22: Zaman-mekan algısının kırılması

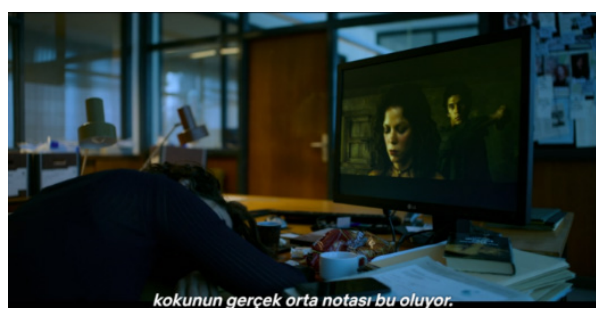

Şekil 23: Koku: Bir Katilin Hikayesi (2006) 


\title{
Postmodern Elements in the New German Realistic Television Dramas
}

\author{
Hasan Gürkan (Asst. Prof. Dr.) \\ Betül Doğan
}

\section{Extended Abstract}

With the expansion of television platforms, users can easily access productions outside their own countries. These platforms recognize the users, know what kind of productions the users like to watch and share content for their users. Those who prepare visual culture products are not subject to strict rules as they do in traditional television approach and gain freedom while processing subjects. This situation makes them save from preparing products as the government wants.

The study deals with three German-made series, which were recently shot and released on Netflix. The purpose of the study is that how the law people play an important role in the plot of these German dramas in the new period and how the profile of the law people is changed in these productions. In the series Dark (2017), Dogs of Berlin (2018) and Perfume (2018), the law people are examined within the framework of personcharacter reflection and their similarities / differences with the previous lawyer profiles are discussed.

The hypothesis of the study is as follows: The characters, in the plot of Dark (2017), Dogs of Berlin (2018) and Perfume (2018), which are produced by Netflix and screened through Netflix, are represented differently from the mainstream characters in these productions. The most important factor in the analysis of these series is that three of them are broadcast on the same platform, they are recent productions, they are of the same type (crime) and each one has the character of the law person.

Content analysis, which is one of the qualitative research methods, is used in the study. Qualitative analysis is one of the research and knowledge of social events and cases, understanding of people's lifestyles, organizational structures and social change generation processes used by social sciences (Özdemir, 2007: 339). This technique is used in the analysis of visual culture products. Özdemir (2007: 335) states that the researcher develops categories related to the research topic and then, counts the words, sentences or pictures that fall within these categories. In this study, qualitative analysis is carried out by following a deductive path by examining visual documents such as cinema films and series and written documents. In this context, the direct effect of the law people on the story was effective in the selection of these three series. Since the postmodern findings are the most common, the sections of the series were chosen in accordance with the purposive sample. From the serial Dark "Secrets, Past and Present, What Goes around, Comes around"; from the serial Dogs of Berlin serial, "Team, Easy Match, Victory Celebration"; from the serial Parfume "Skatol, Synthesis, Heart Notes" episodes were examined.

The claim of this study is that the profile of the law people in the recent German productions differ from the mainstream. Dark is a series of German-produced and Netflix series that began shooting in 2017, directed by Baran Odar. The concepts of the police identity in the mainstream, such as "not making mistakes, on the right track, discreet" 
change in this series. The postmodern elements in the Dark series are often seen as intertextuality, nostalgia and time-space break. Dogs of Berlin is a German-produced series that began shooting in 2018, directed by Christian Alvart and broadcasted on Netflix. Many of the law people in the series act according to their emotions and are far from the accepted definition of policing. In the series, postmodern elements are given as intertextuality and identity issues. Perfume is a German-produced series, which began filming in 2018, directed by Philipp Kadelbach, and released on Netflix. In the series, the identity of the police in the main stream goes outside. The postmodern elements are also included in the series. These elements are often used as intertextuality and time-space refraction. It is seen that the law people have an important role in their decisions in these series rather than the concepts of power representation, common sense, good person, their emotions and they are reshaped in such a way as to commit crimes and exploiters.

Keywords: Dark, Dogs of Berlin, Perfume, Netflix, Postmodernism. 
